\title{
The effect of applying the eco-driving rules on the exhaust emissions
}

\author{
The article presents the results of measurements of exhaust emissions of commercial vehicle in real traffic conditions. \\ The aim of this study was to initial verification how the driving style affects on the exhaust emissions from vehicle en- \\ gine and fuel consumption. The determinants were the measurements of the concentration of $\mathrm{CO}_{2}$ and others harmful \\ substances emitted to the atmosphere from the power unit of the tested vehicle. In the measurements a portable exhaust \\ emission analyzer was used (PEMS type).
}

Key words: driving style, eco-driving, road tests, exhaust emissions

\section{Wpływ stosowania zasad eco-drivingu na emisję substancji szkodliwych}

W artykule zaprezentowano wyniki pomiarów toksyczności spalin samochodu dostawczego w rzeczywistych warunkach ruchu. Celem badań byto wstęne zweryfikowanie wptywu stylu jazdy kierowcy na emisję substancji szkodliwych $w$ spalinach oraz zużycie paliwa przez pojazd. Do realizacji celu wykonano pomiary emisji drogowej dwutlenku węgla i innych związków szkodliwych spalin emitowanych do atmosfery przez jednostkę napędowa pojazdu. Do pomiarów zawartości poszczególnych zanieczyszczeń gazowych w spalinach wykorzystano mobilną aparaturę do badań toksyczności spalin typu PEMS.

Słowa kluczowe: styl jazdy, eco-driving, badania drogowe, emisja spalin

\section{Introduction}

Recently in the automotive circles has appeared and has been functioning the idea of eco-driving [13]. As the creators of this driving style claim, the practical application of some rules should reduce fuel consumption and at the same time cause less pollution to the environment. One of the most important factors pointed out by the eco-driving instructors is the manner of accelerating. The period of acceleration, particularly its dynamic, to a large extent influences the fuel consumption and quantity of emitted harmful substances [1]. The main rules of eco-driving are based on smooth driving, avoiding unnecessary accelerating and braking. Driving in highest possible gear with the lowest possible engine speed (rpm) is recommended (driving at constant speed). It is also important to employ engine brake by reducing gears - e.g. at approaching traffic lights - instead of neutral position of gearbox (engine idling).

The principles of eco-driving first came into being in Switzerland and Finland in the second half of the 90's in the $20^{\text {th }}$ century. The popularity of this driving style among the drivers is constantly increasing. Basing on the examples of many European countries, also in Poland has recently been observed an increase of interest in hints and guidelines aiming at reduction of fuel consumption by vehicles. As the surveys show, in $200712 \%$ of the surveyed declared their belief in eco-driving reducing fuel consumption [12] while in November 2012 it was already an opinion of $26 \%$ of the surveyed. This 14-percent increase proves that the eco-driving awareness is still an open issue. However, the practical application of the eco-driving rules looks worse. It should be added that the same principles of eco-driving unfortunately are quite vague, which may cause difficulties in their precise application.

\section{Wprowadzenie}

W ostatnich czasach w środowisku motoryzacyjnym pojawiło się i funkcjonuje pojęcie eco-drivingu, czyli tzw. eko-jazdy [13]. Jak twierdzą twórcy tego stylu jazdy, stosowanie w praktyce przez kierowców pewnych reguł (zasad) powinno skutkować najmniejszym zużyciem paliwa, a jednocześnie w najmniejszym stopniu wpływać na zanieczyszczenie środowiska. Jedną z istotniejszych rzeczy, na którą zwracają uwagę instruktorzy eco-drivingu jest sposób rozpędzania pojazdu. Okres rozpędzania pojazdu, a ściślej jego dynamika, odpowiada w głównej mierze za wielkość zużycia paliwa oraz masę wyemitowanych związków szkodliwych [1]. Główne zasady eco-drivingu opierają się na płynnej jeździe, ograniczaniu niepotrzebnych przyspieszeń i hamowań. Należy jeździć na możliwie najwyższym biegu, z możliwie najniższą prędkością obrotową silnika (jazda ze stałą prędkością). Ważne jest także stosowanie hamowania silnikiem przez redukcję biegów - np. w trakcie dojazdu do sygnalizatora świetlnego - w miejsce jazdy wybiegiem (bieg luzem i jałowy silnika).

Założenia eco-drivingu po raz pierwszy sformułowano $\mathrm{w}$ Szwajcarii i Finlandii w drugiej połowie lat dziewięćdziesiątych XX wieku. Popularność stosowania zasad tego sposobu jazdy wśród kierowców stale wzrasta. Wzorem wielu krajów europejskich, także i w Polsce, obserwuje się w ostatnich czasach wzrost zainteresowania wskazówkami i wytycznymi, mającymi na celu m.in. zmniejszenie zużycia paliwa przez pojazdy. Jak wskazują badania ankietowe, w 2007 r. $12 \%$ pytanych osób zadeklarowało, że są przekonani o tym, iż eko-jazda może zmniejszyć zużycie paliwa [12]. W listopadzie 2012 r. uważało tak już $26 \%$ ankietowanych. Ten 14-procentowy wzrost świadczy o tym, że wzrasta świadomość 
With the invention of specialized, portable research equipment, construction of which enabled road tests of vehicles, it has become possible to verify benefits ensuing from application of eco-driving rules outside the laboratory - the test stand measurements. Test of the vehicles' operation in terms of ecology are essential especially in case of toxicity of exhaust gases in dynamic, transient conditions of engine operation. Despite the attempt to reflect those conditions in dynamic research tests (e.g. ETC, WHTC), it is not possible to fully reconstruct real conditions of operation of vehicles of different homologation categories [5, 6, 10, 11]. Due to this fact in recent years the biggest research potential in automotive industry has been focused right on the road tests of vehicles in real traffic conditions [3, 4, 9].

In this article are presented results of test of toxicity of exhaust gases, conducted in road conditions. The tests provided information about emission of harmful gases in the dynamic conditions of urban traffic. The test were conducted in order to initial verify the influence of driving style on the emission of selected components of exhaust gases: carbon monoxide and carbon dioxide, hydrocarbons, nitric oxides, and on the fuel consumption by the tested vehicle. The influence of the driving style on fuel consumption is easily measurable and commonly possible to determine, however in order to determine the content of gaseous substances in the exhaust gases it is necessary to use specialized, portable research equipment such as PEMS (Portable Emissions Measurement System) [7].

\section{Research methodology}

\subsection{Conditions of measurements}

The values of road emission of various harmful exhaust gas components $\left(\mathrm{CO}, \mathrm{CO}_{2}, \mathrm{HC}\right.$ and $\left.\mathrm{NO}_{\mathrm{x}}\right)$ and fuel consumption (expressed in $\mathrm{dm}^{3} / 100 \mathrm{~km}$ ) were obtained as a result of

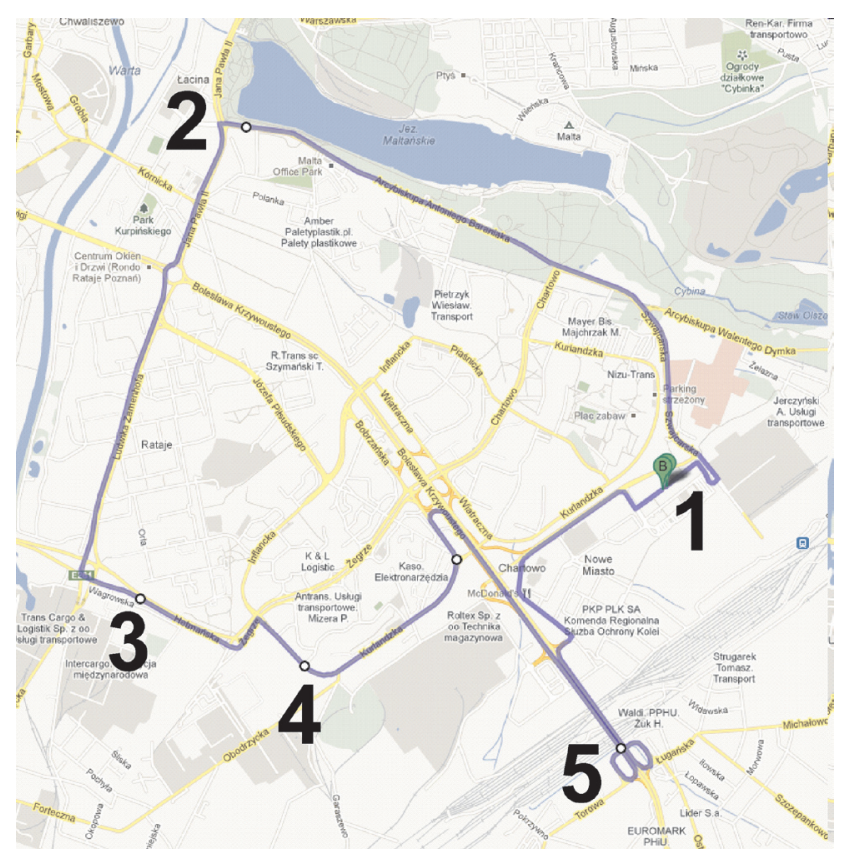

Fig. 1. The test route located in Poznan [2]

Rys. 1. Trasa badawcza zlokalizowana na terenie Poznania [2] dotycząca eco-drivingu. Niezbyt dobrze natomiast przedstawia się stosowanie go w praktycznej jeździe. Należy dodać, że zasady eco-drivingu, niestety, są dość ogólnikowe, co może powodować trudności w ich precyzyjnym stosowaniu.

Od pojawienia się specjalistycznej, mobilnej aparatury naukowo-badawczej, skonstruowanej tak, aby można było prowadzić badania drogowe pojazdów, możliwa stała się weryfikacja korzyści wynikających ze stosowania zasad ecodrivingu poza laboratorium w pomiarach stanowiskowych. Badania pojazdów samochodowych pod kątem ekologii eksploatacji mają znaczenie zwłaszcza w odniesieniu do badań toksyczności spalin w dynamicznych i nieustalonych warunkach pracy silnika. Mimo iż podjęto się odzwierciedlenia tych warunków w dynamicznych testach badawczych (np. ETC, WHTC), nie oddają one jednak w pełni rzeczywistych warunków eksploatacji pojazdów różnych kategorii homologacyjnych $[5,6,10,11]$. Dlatego w ciągu ostatnich kilku lat największy potencjał badawczy w środowisku motoryzacyjnym skoncentrowano właśnie na badaniach drogowych pojazdów w rzeczywistych warunkach ruchu [3, 4, 9].

W niniejszym artykule przedstawiono wyniki badań toksyczności spalin samochodu dostawczego wykonane w warunkach drogowych. Badania dostarczyły informacji na temat emisji gazowych substancji szkodliwych w dynamicznie zmieniających się warunkach ruchu miejskiego. Przeprowadzono je w celu wstępnej weryfikacji wpływu stylu jazdy kierowcy na emisję wybranych składników spalin: tlenku i dwutlenku węgla, węglowodorów, tlenków azotu oraz zużycia paliwa przez badany pojazd. Wpływ sposobu jazdy na zużycie paliwa jest łatwo mierzalny i powszechnie możliwy do określenia, natomiast w celu określenia zawartości gazowych związków chemicznych w spalinach należy posłużyć się już specjalistyczną, mobilną aparaturą badawczą typu PEMS (Portable Emissions Measurement System) [7].

\section{Metodyka badań}

\subsection{Warunki przeprowadzania pomiarów}

Wartości emisji drogowej poszczególnych szkodliwych gazowych składników spalin $\left(\mathrm{CO}, \mathrm{CO}_{2}, \mathrm{HC}\right.$ i NO ), a przy tym także przebiegowego zużycia paliwa przez badany pojazd - wyrażanego $\mathrm{w} \mathrm{dm} 3 / 100 \mathrm{~km}$, uzyskano w efekcie wykonania pomiarów stężeń wymienionych związków i natężenia przepływu spalin w rzeczywistych warunkach ruchu podczas przejazdów na terenie Poznania. Przebieg trasy badawczej zaprezentowano na rys. 1. Jej sumaryczna długość wynosiła około $15 \mathrm{~km}$ (tab. 1). Charakterystyka trasy była zróżnicowana pod względem warunków ruchu. Składała się bowiem z odcinków o ruchu typowo miejskim, jak również pozamiejskim, gdy istniała możliwość uzyskania większej prędkości jazdy (70-80 km/h).

Obraną trasę badawczą ze względu na wspominaną zmienność parametrów ruchu podzielono na pięć części (odcinków pomiarowych):

- ruch miejski o dużym natężeniu - duży udział postoju pojazdu (około $4,5 \mathrm{~km}-30 \%$ trasy przejazdu),

- ruch miejski o małym natężeniu $(2,5 \mathrm{~km}$ - $16 \%$ trasy przejazdu), 
the performance of road tests in the city of Poznan. The vehicle test route is shown in Fig. 1. The length of the route was about $15 \mathrm{~km}$ (Tab. 1). The route was diversified and included a typical urban portion and an extra-urban portion, where it was possible to drive with higher speeds $(70-80 \mathrm{~km} / \mathrm{h})$.

Due to the variability of the traffic parameters the route was divided into five measurement portions:

- urban traffic with high intensity - a large part of stoppage of the vehicle (approximately $4.5 \mathrm{~km}-30 \%$ of the tested route),

- urban traffic with low intensity $(2.5 \mathrm{~km}-16 \%$ of the tested route),

- extra urban traffic - expressway, speed limit of $70 \mathrm{~km} / \mathrm{h}(1 \mathrm{~km}-6 \%$ of the tested route),

- mixed traffic - part of the portion is an expressway, speed limit of $80 \mathrm{~km} / \mathrm{h}$ (approximately $4 \mathrm{~km}-26 \%$ of the tested route),

- mixed traffic - part of the portion are internal roads (approximately $3 \mathrm{~km}$ $22 \%$ of the tested route).

During the test, driving conditions and concentrations of harmful substances of exhaust gases were measured in three test runs named, respectively: eco-driving, normal driving and aggressive driving. Definitions of particular driving styles are as follows:

- eco-driving - moderate acceleration, change of gear at $\mathrm{n}=2000-2500 \mathrm{rpm}$, driving in the $5^{\text {th }}$ gear if only possible, engine brake - reduction of gears while e.g. approaching traffic lights,

- normal driving - slow acceleration, change of gear at $\mathrm{n}=2500-3000 \mathrm{rpm}$, driving maximum in $4^{\text {th }}$ gear, driving in neutral position of gearbox (engine idling), while approaching e.g. traffic lights,

- aggressive driving - dynamic acceleration, change of gear at engine speed over $3000 \mathrm{rpm}$, driving maximum in $4^{\text {th }}$ gear, approaching traffic lights - "sharp" braking from relatively high speed in the final phase of approaching.

\subsection{Research object and the measuring equipment}

Tests in real road conditions were conducted with the use of a commercial vehicle - LDV type (Light Duty Vehicle): it was a delivery van Peugeot Expert with 4-cylinder compression ignition (CI) engine with capacity of $1.9 \mathrm{dm}^{3}$ (Fig. 2). Detailed technical specification of the engine is presented in Table 2. The tested vehicle was equipped with 5 -speed manual gearbox. The vehicle was not equipped with any exhaust aftertreatment system, such as Diesel Particulate Filter (DPF) or Diesel Oxidation Catalyst (DOC). In everyday exploitation it is used to transport loads up to $800 \mathrm{~kg}$. Complete kerb weight of the commercial vehicle

- ruch pozamiejski - droga szybkiego ruchu, prędkość dopuszczalna $70 \mathrm{~km} / \mathrm{h}(1 \mathrm{~km}-6 \%$ trasy przejazdu),

- ruch mieszany - część odcinka to droga szybkiego ruchu, prędkość dopuszczalna $80 \mathrm{~km} / \mathrm{h}$ (około $4 \mathrm{~km}-26 \%$ trasy przejazdu),

- ruch mieszany - część odcinka to drogi wewnętrzne (około $3 \mathrm{~km}-22 \%$ trasy przejazdu).

Table 1. The characteristics of the test route

Tabela 1. Charakterystyka trasy badawczej

\begin{tabular}{c|c|c} 
Stop/ & Length/dlugość [km]
\end{tabular} (share in the test/udziat w teście)

\begin{tabular}{|c|c} 
koniec & w teście $)$ \\
\hline
\end{tabular}

\begin{tabular}{|c|c|}
\hline dlowe & Politechnika Poznańska \\
\hline
\end{tabular}


The effect of applying the eco-driving rules on the exhaust emissions

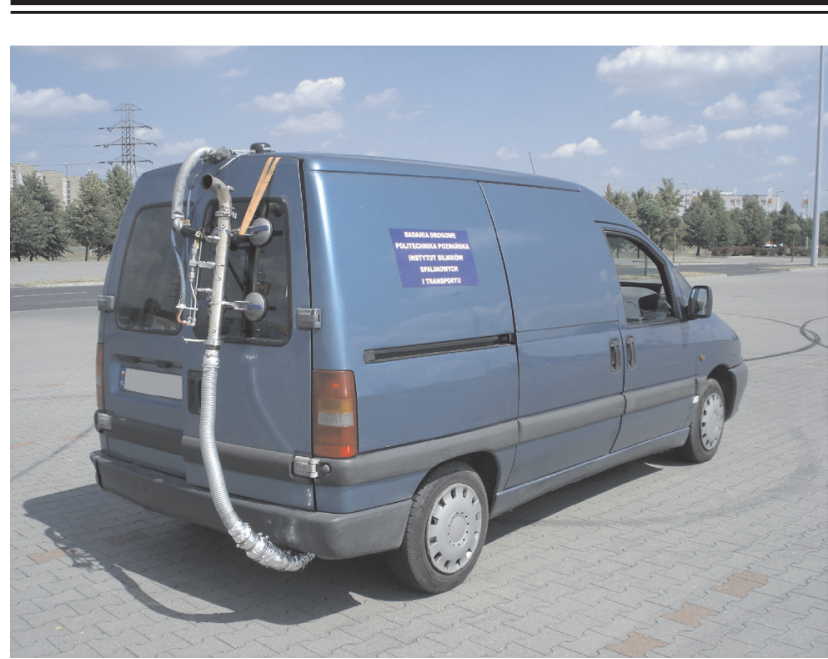

Fig. 2. Peugeot Expert prepared to the road tests

Rys. 2. Peugeot Expert przygotowany do badań drogowych

selected for tests did not exceed $2610 \mathrm{~kg}$. Thus, it belonged to a group of vehicles subjected to homologation tests on chassis dynamometer test stand complying with the New European Driving Cycle (NEDC) [10].

For measuring concentration of harmful substances in the exhaust gases was used a portable system PEMS intended for determining the content of gaseous components of the exhaust gases (Fig. 3). The system - Semtech-DS by Sensors Inc. - consists mainly of the set of chemical analysers corresponding to given substances, the exhaust flow

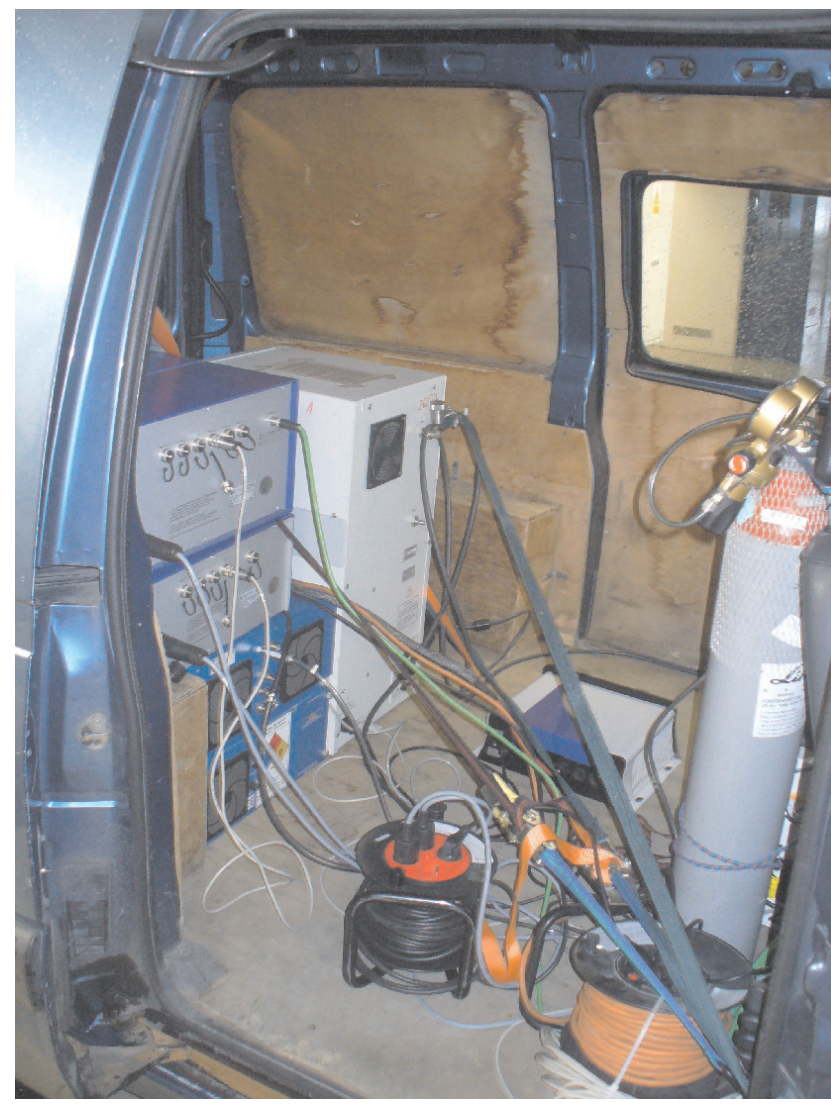

Fig. 3. Measuring equipment (PEMS type) mounted on the vehicle Rys. 3. Aparatura pomiarowa typu PEMS zamontowana w pojeździe
Table 2. The basic specifications of the vehicle used in tests

Tabela 2. Podstawowe dane techniczne badanego samochodu

\begin{tabular}{|c|c|}
\hline \multirow{2}{*}{$\begin{array}{l}\text { Parameter/ } \\
\text { parametr }\end{array}$} & $\begin{array}{l}\text { Research object/ } \\
\text { obiekt badań }\end{array}$ \\
\hline & Peugeot Expert \\
\hline Type of engine/rodzaj silnika & $\mathrm{CI} / \mathrm{ZS}$ \\
\hline $\begin{array}{l}\text { Cylinder number and configuration/ } \\
\text { uktad i liczba cylindrów }\end{array}$ & R4 \\
\hline Displacement/objętość skokowa $\left[\mathrm{dm}^{3}\right]$ & 1.9 \\
\hline Fuel injection system/układ wtryskowy & $\begin{array}{l}\text { rotary pump/pompa } \\
\text { rozdzielaczowa }\end{array}$ \\
\hline $\begin{array}{l}\text { Maximum power output/moc maksymal- } \\
n a[\mathrm{~kW} / \mathrm{KM}] \text { at } / \text { przy }[\mathrm{rpm}] /[\mathrm{obr} / \mathrm{min}]\end{array}$ & $\begin{array}{r}68 / 92 \\
4000 \\
\end{array}$ \\
\hline $\begin{array}{l}\text { Maximum torque/maksymalny moment } \\
\text { obrotowy }[\mathrm{N} \cdot \mathrm{m}] \text { at } / \text { przy }[\mathrm{rpm}] /[\text { obr/min }]\end{array}$ & $\begin{array}{l}196 \\
2250\end{array}$ \\
\hline Supercharging/doładowanie & $\begin{array}{l}\text { turbocharger/ } \\
\text { turbosprężarka }\end{array}$ \\
\hline Transmission/skrzynia przektadniowa & $\begin{array}{l}\text { manual, } 5 \text { gears/ } \\
\text { manualna, } 5 \text { biegów }\end{array}$ \\
\hline $\begin{array}{l}\text { Aftertreatment system/uklad } \\
\text { oczyszczania spalin }\end{array}$ & lack/brak \\
\hline Vehicle weight/masa pojazdu $[\mathrm{kg}]$ & 1400 \\
\hline Power index/wskaźnik mocy $\left[\mathrm{kW} / \mathrm{dm}^{3}\right]$ & 36 \\
\hline Weight index/wskaźnik masy $[\mathrm{kg} / \mathrm{kW}]$ & 21 \\
\hline
\end{tabular}

Oxidation Catalyst). W codziennej eksploatacji służy on do transportu ładunków o masie do $800 \mathrm{~kg}$. Masa własna wybranego do pomiarów samochodu użytkowego nie przekracza $2610 \mathrm{~kg}$. Należy on zatem do grupy pojazdów podlegających badaniom homologacyjnym na podwoziowym stanowisku dynamometrycznym - hamowni podwoziowej - według europejskiego cyklu jezdnego NEDC (New European Driving Cycle) [10].

W celu dokonania pomiarów stężenia substancji szkodliwych w spalinach posłużono się mobilną aparaturą typu PEMS przeznaczoną do określania zawartości gazowych składników spalin (rys. 3). Aparatura ta - Semtech-DS firmy Sensors Inc. - składa się w głównej mierze z zestawu odpowiednich dla danych związków chemicznych analizatorów, z przepływomierza spalin (o różnej średnicy, w zależności od wydatku spalin z układu wylotowego pojazdu), z modułu pozwalającego na rejestrację danych z systemu diagnostyki pokładowej OBD pojazdu (On-Board Diagnostics) oraz $\mathrm{z}$ modułu umożliwiającego komunikację z systemem lokalizacji GPS, dzięki czemu można nanieść wyniki pomiarów na trasę przejazdu [8].

Jednym z analizatorów wchodzących w skład urządzenia Semtech-DS jest analizator niedyspersyjny na podczerwień NDIR (Non-Dispersive Infrared). Ta niedyspersyjna metoda pomiaru z wykorzystaniem promieniowania podczerwonego pozwala wyznaczyć, konieczne do dokonywanej $\mathrm{w}$ artykule analizy, stężenie dwutlenku węgla w spalinach (NDIR mierzy również stężenie tlenku węgla). Kolejnymi z analizatorów, będących elementami budowy opisywanej aparatury badawczej, są NDUV (Non-Dispersive Ultraviolet) oraz FID (Flame Ionization Detector). Pierwszy z nich umożliwia pomiar stężenia tlenków azotu, a drugi służy do 
meter (with different diameter depending on the flow rate of exhaust gases from the exhaust system of the vehicle), the module recording data from the On-Board Diagnostics system (OBD) and the module for communication with the Global Positioning System (GPS) enabling marking the measurement results on the driving route [8].

One of the analysers included in the Semtech-DS system is the Non-Dispersive Infrared analyser (NDIR). This nondepressive measuring method utilizing infrared radiation enables to determine, essential for the analysis conducted in the article, concentration of the carbon dioxide in the exhaust gases (NDIR measures also concentration of carbon monoxide). Other analysers included in the described research equipment, are Non-Dispersive Ultraviolet (NDUV) and Flame Ionization Detector (FID). The first enables measurements of the nitric oxides concentration and the other is used for determining hydrocarbons content in the exhaust gases. The system - apart from measuring concentration of individual harmful gaseous substances - allows also measuring mass flow of exhaust gases (flow meter). It is essential for measuring emission of these substances (e.g. road emissions). Semtech-DS also allows determining e.g. mileage fuel consumption for the tested vehicle utilizing so-called carbon balance method.

\section{Road tests results}

In order to determine driving conditions for each of the three analysed test runs for the tested delivery van - eco-, normal and aggressive driving utilizing, among the others, using data from the on-board diagnostic system (OBD), a number of basic driving parameters have been compared: vehicle's acceleration, driving with constant speed and stoppage. Sample comparison of the driving conditions for one of the portions of the tested route is presented in Fig. 4. Due to the character of the tests, which were conducted in real road conditions, the values of driving parameters for analysed test runs are slightly different. It is particularly noticeable for the time of covering a given measurement route.

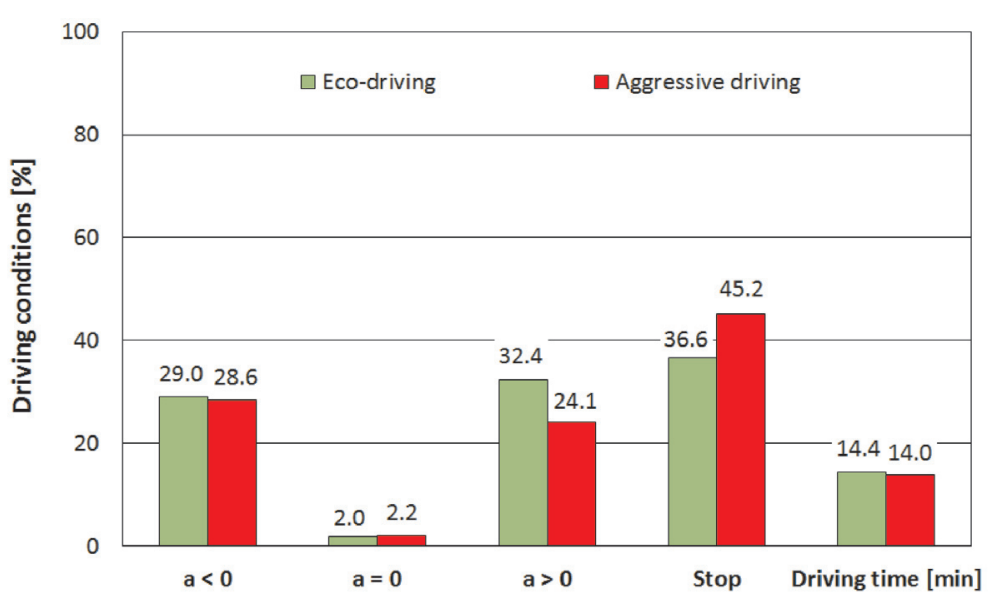

Fig. 4. The share of the driving conditions for portion $1 \mathrm{~A}-2$ Rys. 4. Udział warunków jazdy na odcinku 1A-2 określenia zawartości węglowodorów w spalinach. Opisywana aparatura - oprócz pomiaru stężenia poszczególnych gazowych substancji szkodliwych - umożliwia także pomiar masowego natężenia przepływu spalin (przepływomierz). Jest to niezbędne do obliczania emisji (np. drogowej) tych związków. Ponadto urządzenie Semtech-DS pozwala wyznaczyć m.in. przebiegowe zużycie paliwa przez badany pojazd, wykorzystując tzw. metodę bilansu węgla (carbon balance).

\section{Wyniki badań}

W celu określenia warunków jazdy w każdym z trzech analizowanych przejazdów - eco-driving, jazda normalna i agresywna - badanym samochodem dostawczym, między innymi przy wykorzystaniu danych pochodzących z systemu diagnostyki pokładowej OBD pojazdu, dokonano zestawienia kilku podstawowych parametrów ruchu: przyspieszenie pojazdu, jazda ze stała prędkością, postój. Przykładowe porównanie warunków jazdy dla jednego z odcinków pomiarowych przedstawiono na rys. 4 . Z powodu charakteru badań, przeprowadzanych w warunkach ruchu rzeczywistego, wartości parametrów ruchu dla analizowanych przejazdów nieznacznie się różnią. Świadczy o tym zwłaszcza czas przejazdu danego odcinka pomiarowego.

Bazując na zmierzonym stężeniu szkodliwych składników w spalinach, obliczono natężenie emisji dla wszystkich pięciu odcinków pomiarowych. Przykładowy przebieg natężenia emisji dwutlenku węgla dla jednego z odcinków pomiarowych przedstawiono na rys. 5. Podobnie jak w odniesieniu do udziału warunków ruchu, także i tu, dla lepszego zobrazowania różnic w wartości natężenia emisji, na wykresie ograniczono się jedynie do dwóch „skrajnych” stylów jazdy.

Na podstawie otrzymanego w wyniku obliczeń natężenia emisji obliczono w dalszej kolejności emisję drogową analizowanych związków gazowych dla każdego odcinka pomiarowego oraz całej trasy badawczej, określaną w g/km (rys. 6). Jak można zauważyć, przejazdy poszczególnych odcinków pomiarowych w zakresie zmienności stylu jazdy kierowcy cechują się różną specyfiką emisji szkodliwych składników spalin $\mathrm{CO}, \mathrm{CO}_{2}, \mathrm{HC}$ i $\mathrm{NO}_{x}$.

W wyniku przeprowadzonych badań odnotowano dla eco-drivingu najmniejszą, a dla stylu jazdy agresywnej największą emisję drogową wszystkich analizowanych substancji szkodliwych emitowanych z układu wylotowego pojazdu badawczego. $\mathrm{Na}$ zauważalne większe lub mniejsze różnice w poziomie emisji składników spalin, określonym dla analizowanych odcinków pomiarowych, mogą w pewnym stopniu mieć wpływ nieco inne warunki panujące na drodze podczas wykonywania jazd testowych. Przykładowo jest to większe zjawisko kongestii drogowej, a tym samym większy udział postoju pojazdu.

Odnośnie do emisji drogowej tlenku węgla dla całej trasy badawczej odnotowano 
Based on the measured concentration of harmful components of exhaust gases, the intensity of emission for all five measurement routes was calculated. Exemplary characteristics of carbon dioxide emissions intensity for one of the portions of the tested route are presented in Fig. 5. Similarly to the driving conditions, also here for clarity differences in the emission intensity values in the graph are merely two "extreme" driving styles.

On the basis of the calculated emission intensity, the road emission of the analysed gaseous substances (expressed in $\mathrm{g} / \mathrm{km}$ ) was determined for each part of the measurement route separately as well as for the whole route (Fig. 6). It can be observed that drive times for individual measurement routes for different driving styles vary in terms of emission characteristics of harmful components of exhaust gases such as $\mathrm{CO}, \mathrm{CO}_{2}, \mathrm{HC}$ and $\mathrm{NO}_{\mathrm{x}}$.

a)

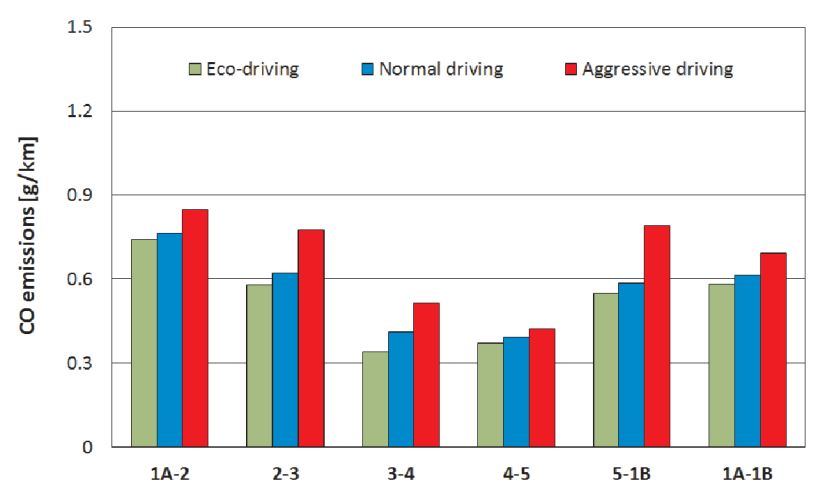

c)

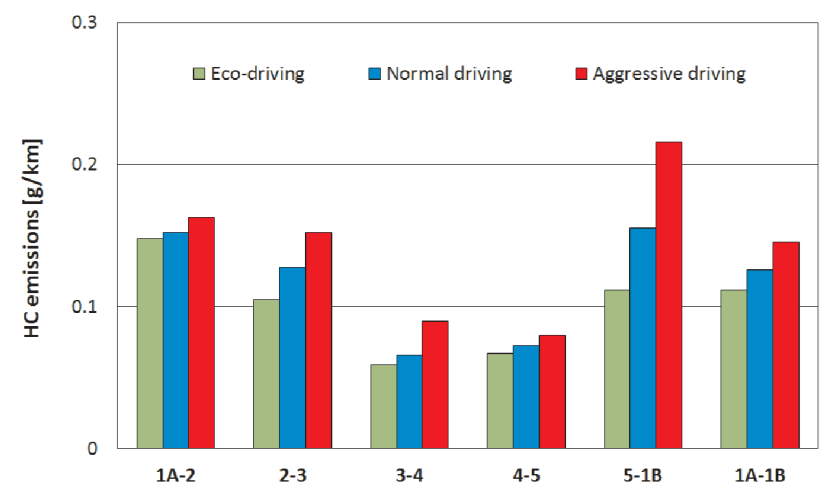

w kolejności około: 0,58, 0,61 i 0,69 g/km. Daje to różnice procentowe względem jazdy normalnej na poziomie $-4,7 \%$ dla eco-drivingu oraz 12,9\% dla jazdy agresywnej (rys. 7a).

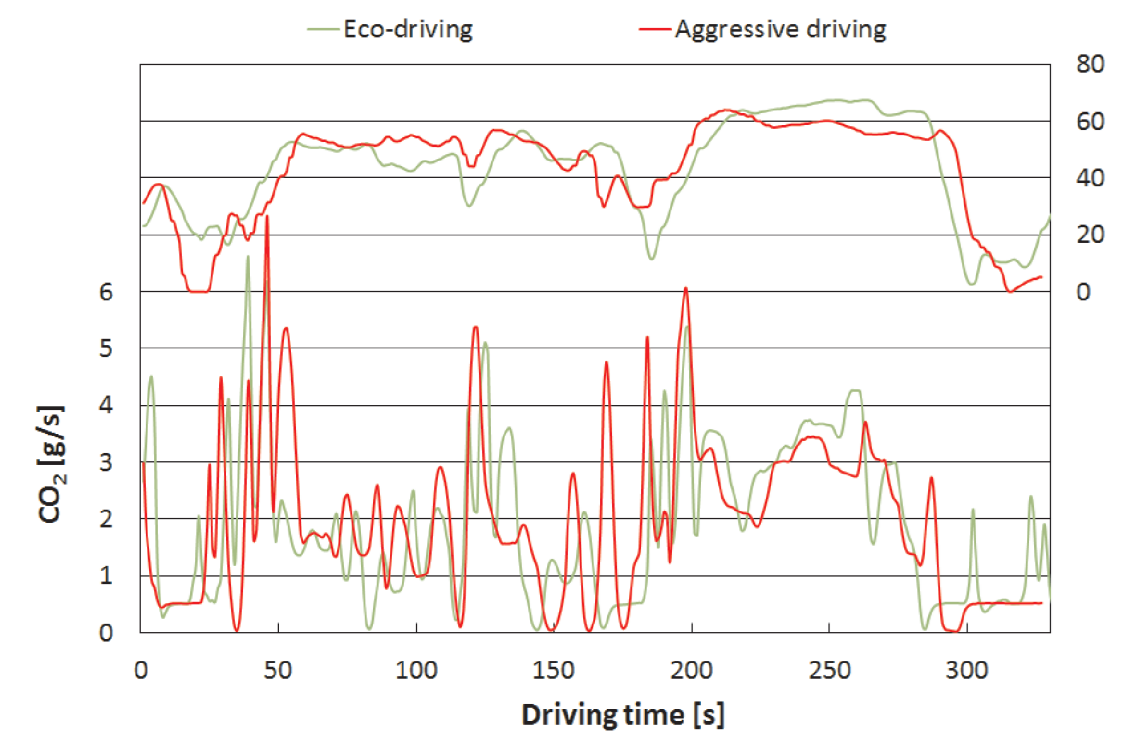

Fig. 5. Emission intensity of carbon dioxide for portion 4-5 Rys. 5. Natężenie emisji dwutlenku węgla na odcinku 4-5

b)

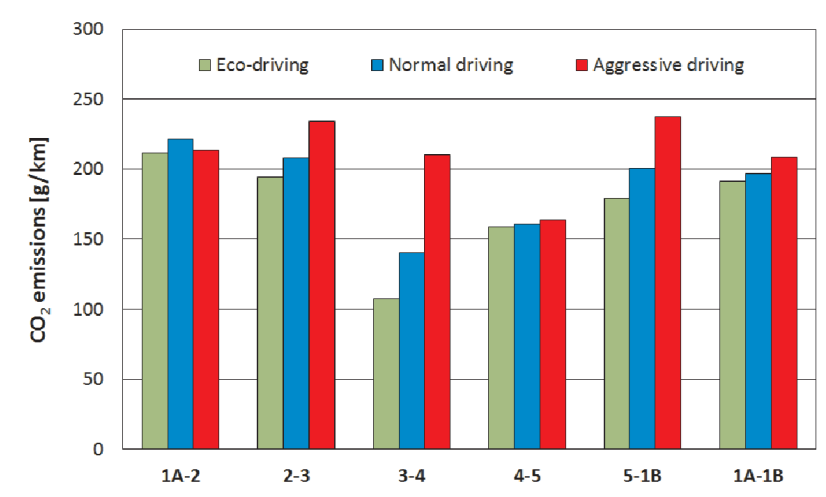

d)

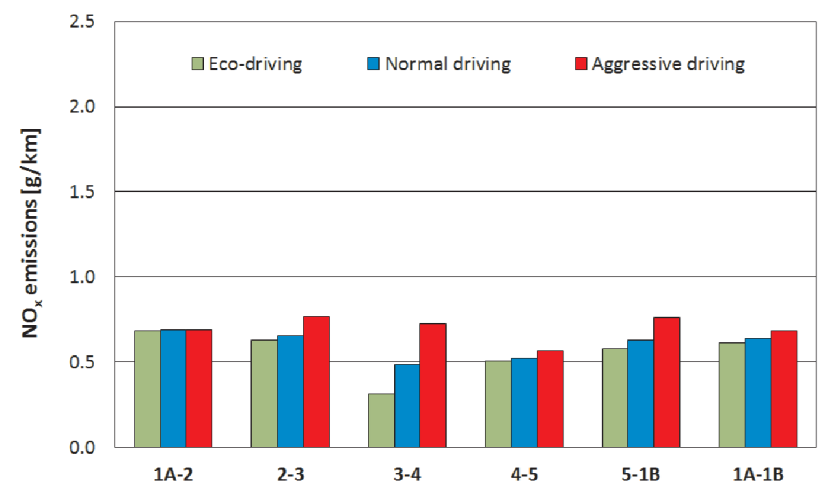

Fig. 6. Road emissions for each measurement portions: a) carbon monoxide, b) carbon dioxide, c) hydrocarbons, d) nitric oxides Rys. 6. Wartości emisji drogowej dla poszczególnych odcinków pomiarowych: a) tlenku węgla, b) dwutlenku węgla, c) węglowodorów, d) tlenków azotu 
a)

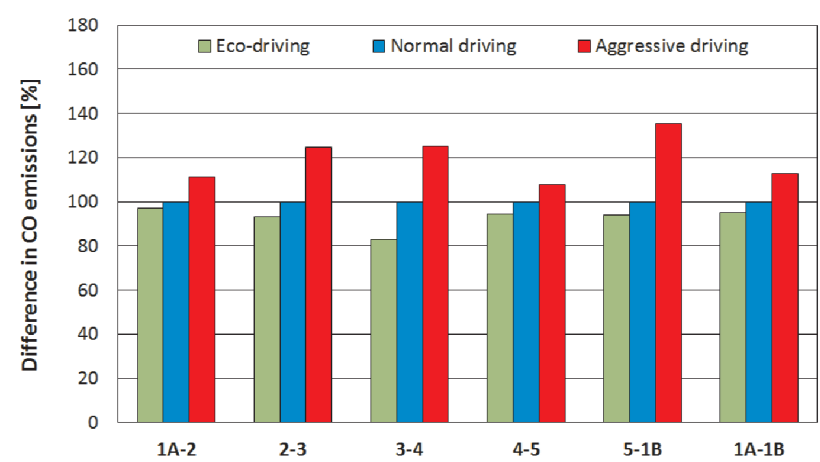

c)

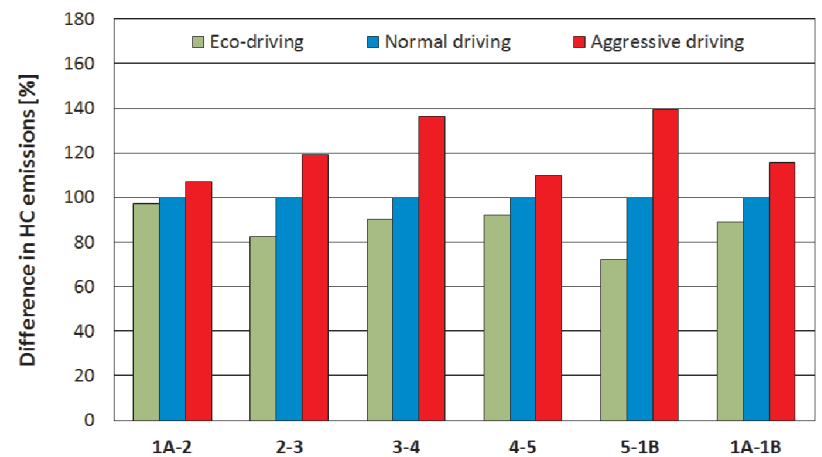

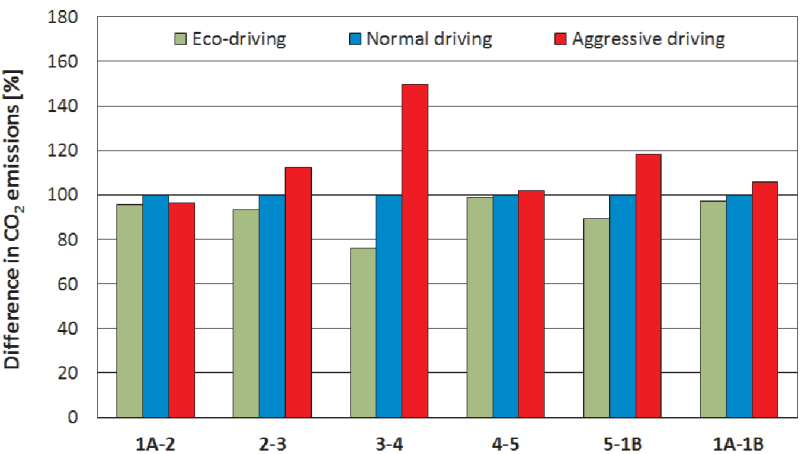

d)

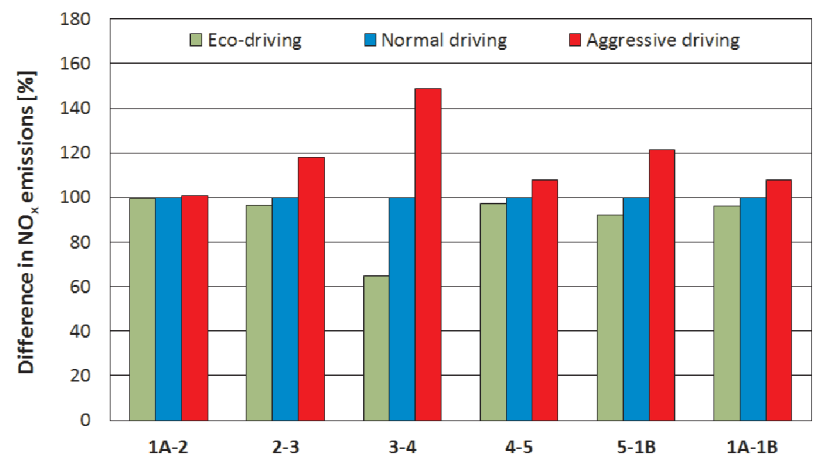

Fig. 7. Percentage difference in emissions as a result of different driving style (normal driving $=100 \%$ ): a) carbon monoxide, b) carbon dioxide, c) hydrocarbons, d) nitric oxides

Rys. 7. Procentowa różnica $w$ emisji w wyniku zastosowania różnego stylu jazdy (jazda normalna = 100 \%): a) tlenek węgla, b) dwutlenek węgla, c) węglowodory, d) tlenki azotu

As a result of the tests conducted, for driving style called eco-driving were observed the lowest, and for aggressive driving - the highest road emissions of all analysed harmful substances emitted by the exhaust system of the tested vehicle. Visible, smaller or bigger differences in the levels of

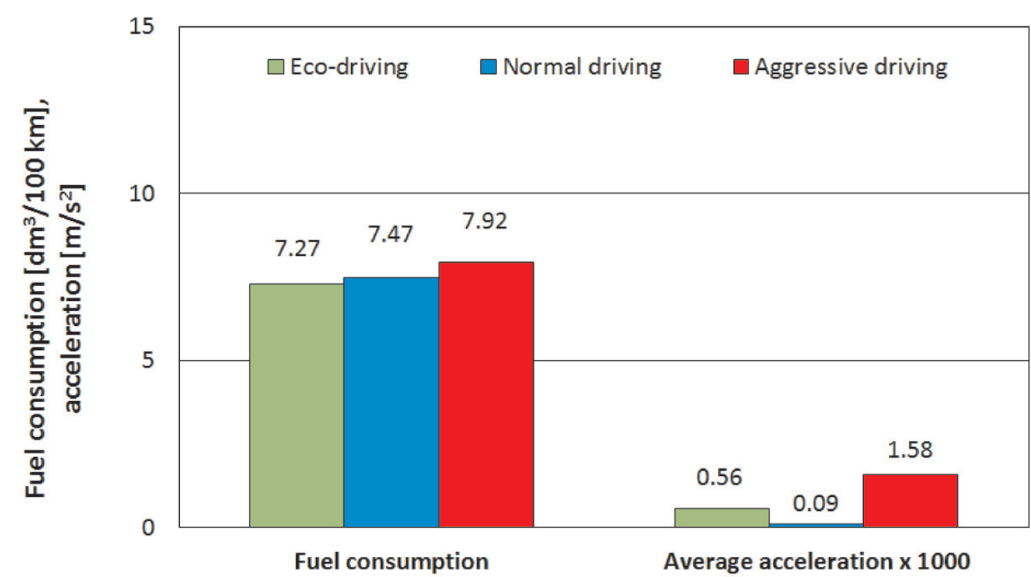

Fig. 8. Fuel consumption specified for the entire test route Rys. 8. Przebiegowe zużycie paliwa określone dla całej trasy przejazdu
Różnice procentowe w emisji drogowej dwutlenku węgla wynoszą odpowiednio: $-2,8$ i 5,9 \% (rys. 7b). Podobne wartości obserwuje się dla emisji tlenków azotu (rys. 7d). W odniesieniu do węglowodorów należy zwrócić szczególną uwagę na ponad 15-procentowy wzrost ich emisji w wyniku zastosowania przez kierowcę agresywnego stylu jazdy - cała trasa przejazdu (rys. 7c).

Oprócz określenia wpływu zastosowanego sposobu jazdy na emisję substancji szkodliwych w spalinach badanego pojazdu użytkowego określono również wpływ tego sposobu na wielkość zużywanego przez pojazd paliwa. Wartość przebiegowego zużycia paliwa dla całej pokonanej trasy, na tle średniego przyspieszenia, zobrazowano na rys. 8 . Różnice względem jazdy normalnej wynoszą: $-0,20$ i $0,45 \mathrm{dm}^{3} / 100 \mathrm{~km}$. Daje to zmniejszenie zużycia paliwa o 2,6\% (eco-driving) oraz zwiększenie o 6,1\% (jazda agresywna; rys. 9). Z analizy rysunków wynika, że wartości te są dużo mniejsze od tych spotykanych 
emission of components of exhaust gases, determined for the analysed measurement routes, can be influenced by slightly different road conditions during test runs, such as bigger road congestion meaning bigger share of vehicle stoppages.

In case of road emission of carbon monoxide for the entire test route, the respective values recorded for each driving style were approximately: 0.58, 0.61 and $0.69 \mathrm{~g} / \mathrm{km}$. The difference in percentage compared to normal driving is $-4.7 \%$ for eco-driving and $12.9 \%$ for aggressive driving (Fig. 7a). The difference in percentage for road emission of carbon dioxide is, respectively: $-2.8 \%$ and $5.9 \%$ (Fig. 7b). Similar values are observed in the case of nitrogen oxides (Fig. 7d). In case of hydrocarbons, over $15 \%$

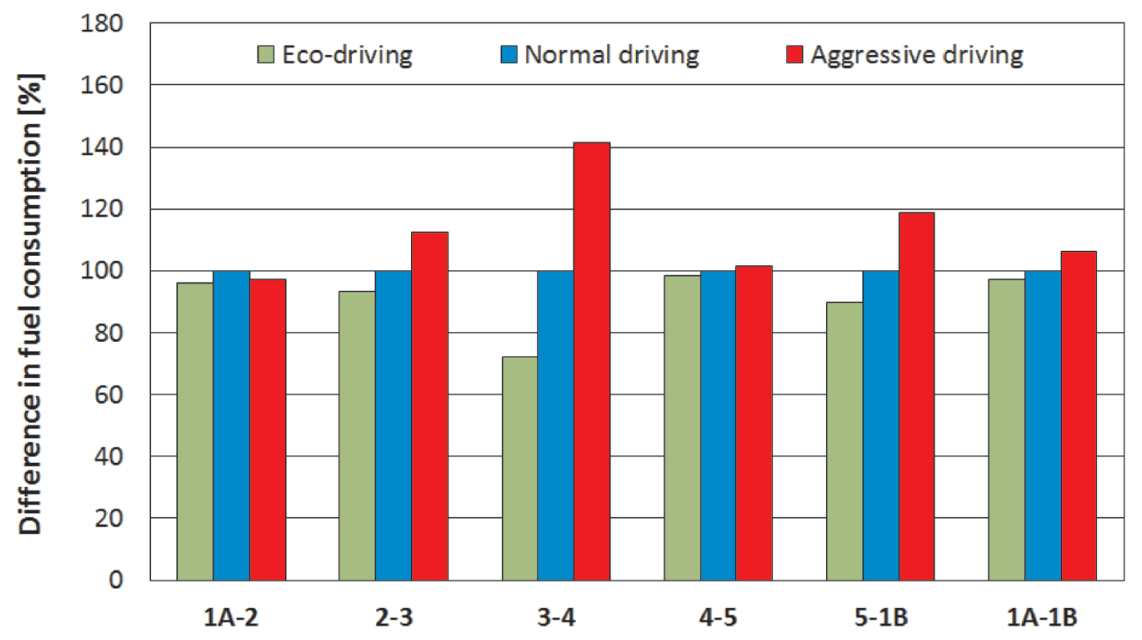
increase of their emission should be pointed out, ensuing from aggressive driving style employed by the driver - for the entire test route (Fig. 7c).

Apart from determining the influence of the applied driving style on the emission of harmful substances in exhaust gases of the tested commercial vehicle, also its influence on the fuel consumption was checked. The mileage fuel consumption value for the entire test route, against the average acceleration, is illustrated in Fig. 8. The differences compared to normal driving are respectively: -0.20 and 0.45 $\mathrm{dm}^{3} / 100 \mathrm{~km}$. It results in reduction of fuel consumption by $2.6 \%$ (for eco-driving) and increase by $6.1 \%$ (for aggressive driving; Fig. 9). As can be seen, these values are much smaller than those found in the declarations of eco-driving instructors (reduce of fuel consumption by $10 \%-30 \%$ ). The discrepancies may be due to the relatively difficult traffic conditions, under which the tests were performed.

\section{Conclusions}

The conducted road tests of delivery van in real conditions of its operation visualized significant influence of the driving style employed by a driver on the road emission of gaseous substances in exhaust gases and on the fuel consumption. A significant increase of road emissions values of those substances should be pointed out for aggressive driving style and a noticeable decrease for ecological and economical driving style - so-called eco-driving. On the road quite often can be observed a dynamic, even very aggressive way of driving. Considering the conclusions from the conducted tests it should be underlined that such driving style might not only adversely influence the efficiency of motor vehicles exploitation - fuel consumption, but also to a large extent the natural environment, people and safety of driving.

It should be pointed out that the conducted tests were just introductory. In order to fully determine the influence of the manner of exploitation of vehicles on their ecologi-

w deklaracjach instruktorów nauki eco-drivingu (zmniejszenie zużycia paliwa w granicach $10 \%$-30\%). Rozbieżności mogą wynikać m.in. ze stosunkowo trudnych warunków ruchu, w jakich wykonywano badania.

\section{Podsumowanie}

Wykonane badania drogowe samochodu dostawczego w rzeczywistych warunkach jego eksploatacji uwidoczniły znaczący wpływ stosowanego przez kierowcę stylu jazdy na emisję gazowych substancji w spalinach oraz zużycie paliwa. Należy wskazać na znaczny wzrost wartości emisji drogowej tych związków w wyniku zastosowania jazdy agresywnej oraz zauważalny spadek wartości emisji przy zastosowaniu ekologicznego i ekonomicznego stylu jazdy eco-drivingu. Na drogach dość często można zaobserwować stosowanie przez kierowców dynamicznego, a nawet bardzo agresywnego sposobu poruszania się pojazdem. Mając na uwadze wnioski wyciągnięte z przeprowadzonych badań, warto podkreślić, że może to nie tylko wpływać negatywnie na ekonomię eksploatacji pojazdów silnikowych - wielkość zużycia paliwa, ale również - i to w dużym stopniu - na środowisko naturalne i człowieka oraz bezpieczeństwo jazdy.

Należy zasygnalizować, iż wykonane badania były jedynie badaniami wstępnymi. W celu pełniejszego określenia wpływu sposobu eksploatacji pojazdów na ich właściwości ekologiczne i energochłonność ruchu należy rozszerzyć prace badawcze o większą liczbę przejazdów oraz wykonać pomiary toksyczności spalin na trasach o innej charakterystyce, w tym w ruchu autostradowym. Kierunkiem dalszych prac będzie również przeprowadzenie badań pojazdów innych kategorii i z różnym rodzajem napędu - wyposażonych w napęd konwencjonalny (jako jednostka napędowa wyłącznie silnik ZI lub ZS) bądź alternatywny (np. hybrydowy, LPG, CNG). Ponadto przewiduje się dokonanie analizy wpływu eco-drivingu na emisję masową, w tym rozkład wymiarowy, 
cal characteristics and energy consumption the test should cover bigger number of vehicles and the tests of toxicity of the exhaust gases should be conducted on routes with different characteristics, including motorway traffic. Our further research will include tests on vehicles of other categories and with different types of drive - equipped with conventional engines (as the drive unit only compression ignition or spark ignition engine) or alternative drives (e.g. hybrid drive system, LPG or CNG). We also plan to conduct the analysis of eco-driving on mass emission, including particle size distribution and particulate number $(\mathrm{PN})$.

The research was funded by the National Science Centre Poland (Narodowe Centrum Nauki) - PhD research project No. N N509 562340 (contract No. 5623/B/T02/2011/40).

\section{Nomenclature/Skróty i oznaczenia}

CI Compression Ignition/silnik o zapłonie samoczynnym (ZS)

CNG Compressed Natural Gas/sprężony gaz ziemny

DOC Diesel Oxidation Catalyst/utleniajacy reaktor katalityczny dla silników ZS

DPF Diesel Particulate Filter/filtr czastek statych

ETC European Transient Cycle/europejski test dynamiczny dla pojazdów ciężkich

FID Flame Ionization Detector/analizator płomieniowo-jonizacyjny

GPS Global Positioning System/system nawigacji satelitarnej

LDV Light Duty Vehicle/lekki pojazd użytkowy

LPG Liquefied Petroleum Gas/skroplona mieszanina propanu i butanu

NDIR Non-Dispersive Infrared/analizator niedyspersyjny na podczerwień

NDUV Non-Dispersive Ultraviolet/analizator niedyspersyjny na ultrafiolet

NEDC New European Driving Cycle/europejski cykl jezdny dla pojazdów lekkich

OBD On-Board Diagnostics/system diagnostyki pokładowej pojazdu

PEMS Portable Emissions Measurement System/aparatura mobilna do badań toksyczności spalin

PN Particulate Number/liczba czastek stalych

WHTC World Harmonized Transient Cycle/test dynamiczny dla pojazdów ciężkich obowiazujący od normy Euro VI

Prof. Jerzy Merkisz, DSc., DEng. - Professor in the Faculty of Machines and Transport at Poznan University of Technology.

Prof. Jerzy Merkisz - profesor na Wydziale Maszyn Roboczych i Transportu Politechniki Poznańskiej.

e-mail: jerzy.merkisz@put.poznan.pl

Maciej Andrzejewski, MSc, Eng. - PhD student at the Faculty of Machines and Transport at Poznan University of Technology.

Mgr inż. Maciej Andrzejewski - doktorant na Wydziale Maszyn Roboczych i Transportu Politechniki Poznańskiej.

e-mail: maciej.andrzejewski@doctorate.put.poznan.pl cząstek stałych oraz na liczbę tych cząstek (PN - Particulate Number).

Badania zostały sfinansowane ze środków Narodowego Centrum Nauki - projekt badawczy promotorski nr N N509 562340 (umowa $n$ r 5623/B/T02/2011/40).

\section{Bibliography/Literatura}

[1] Casanova J., Barrios C., Espinosa F.: Capability of on-board emission measurement systems for driver behavior assessment. International Conference on Transport and Environment: A global challenge, Technological and Policy Solutions, Milan 19-21 March 2007.

[2] Merkisz J., Andrzejewski M.: Wpływ eco-drivingu na emisję dwutlenku węgla z samochodu dostawczego, AUTOBUSY: Technika, Eksploatacja, Systemy Transportowe 3, 3013, s. 193-202.

[3] Merkisz J., Kozak M., Molik P., Nijak D., Andrzejewski M., Nowak M., Rymaniak Ł., Ziółkowski A.: The analysis of the emission level from a heavy-duty truck in city traffic, Combustion Engines, No. 3/2012 (150), p. 80-88.

[4] Merkisz J., Pielecha J.: The on-road exhaust emissions characteristics of SUV vehicles fitted with diesel engines. Combustion Engines, No. 2/2011 (145), p. 58-72.

[5] Merkisz J., Pielecha J., Radzimirski S.: Emisja zanieczyszczeń motoryzacyjnych w świetle nowych przepisów Unii Europejskiej. Wydawnictwa Komunikacji i Łączności, Warszawa 2012.

[6] Regulation (EC) No. 510/2011 of the European Parliament and of the Council of 11 May 2011 Setting Emission Performance Standards for New Light Commercial Vehicles as Part of the Community's Integrated Approach to Reduce $\mathrm{CO}_{2}$ Emissions from Light-Duty Vehicles. OJ L 145/1.

[7] Rubino L., Bonnel P., Carriero M., Krasenbrink A.: Portable emission measurement system (PEMS) for heavy duty diesel vehicle PM measurement: the European PM PEMS program. SAE Technical Paper Series 2009-24-0149.

[8] Shahinian V.D.: SENSOR Tech-CT Update Application Software for SEMTECH Mobile Emission Analyzers. Sensors $4^{\text {th }}$ Annual SUN (SEMTECH User Network) Conference, Ann Arbor 22.10.2007.

[9] Walsh M.: Global trends in motor vehicle pollution control: a 2011 update. Part 2. Combustion Engines, No. 3/2011 (146), p. 53-58.

[10] Worldwide Emissions Standards. Passenger Cars and Light Duty Vehicles. Delphi 2012/2013 (www.delphi.com).

[11] Worldwide Emissions Standards. Heavy Duty and OffHighway Vehicles. Delphi 2012/2013 (www.delphi.com).

[12] autonews.iogloszenia.com, dostęp z dnia 27.03.2013.

[13] www.vda.de, dostęp z dnia 26.03.2013.

Jacek Pielecha, DSc. DEng. - doctor in the Faculty of Machines and Transport at Poznan University of Technology.

Dr hab. inż. Jacek Pielecha-adiunkt na Wydziale Maszyn Roboczych i Transportu Politechniki Poznańskiej.

e-mail: jacek.pielecha@put.poznan.pl

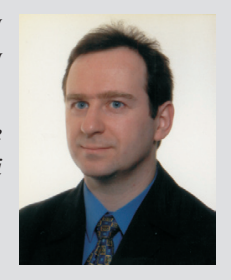

